\title{
Cizí geny, naše dítě? Rozhodování o rodičovství v procesu léčby neplodnosti ${ }^{1}$
}

\author{
Others' Genes, Our Baby? Parenthood Decision-Making during \\ Infertility Treatment
}

Lenka Slepičková

\begin{abstract}
This paper is concerned with involuntary childlessness resulting from physical infertility and its medicalization through the use of reproductive technologies. The research is based on the sociological perspective of constructivism and exploits analytical material consisting of 36 in-depth interviews (with 5 men and 31 women) who share their experiences with infertility treatment. The analysis focuses on the different approaches to decision-making by couples about infertility treatment and future parenthood. It refers to the geneticization of parental ties and also to the means of manipulation of various types of parental relations in order to fulfil a society-based image about parenthood. It also draws attention to adoption, which in certain contexts may become a preferred choice for infertile couples.
\end{abstract}

KEYWORDS infertility, adoption, geneticization, parenthood

Neplodným párům se, zvláště v České republice díky liberální legislativě týkající se rozsahu dostupných procedur, nabízí několik medicínských i nemedicínských možností řešení neplodnosti. Výběr je, také vzhledem $\mathrm{k}$ tomu, že část léčby je přímo hrazena těmi, kdo ji využívají, do značné míry na nich. Kromě finančních limitů (ze zdravotního pojištění jsou hrazeny tři pokusy o umělé oplodnění za použití základních léků a postupů) je oficiálním limitem léčby stabilní heterosexuální vztah budoucích rodičů (respektive povinnost budoucího otce dítěte souhlasit s léčbou a přihlásit se k otcovství) a dodržení věkové hranice, která je stanovena na 39 let věku ženy pro léčbu hrazenou pojišt'ovnou (horní věkový limit pro nehrazenou léčbu zákon nestanovuje, a ten tedy záleží na vnitřních pravidlech jednotlivých zařízení pro léčbu neplodnosti). $\mathrm{V}$ průběhu léčby musí neplodné páry učinit celou řadu rozhodnutí o jejím pokračování, konkrétní podobě a jejím ukončení. Musí zvažovat náklady a rizika a také to, co vše je ve snaze o zvýšení šance na početí přijatelné.

Dostupnost léčby neplodnosti může normy týkající se reprodukce upevnit i narušit, případně ustavit normy nové. Povaha normativního a hodnotového kontextu rozhodování,

Sociální studia. Katedra sociologie FSS MU, 4/2011. S. 125-144. ISSN 1214-813X.

1 Tato studie vznikla s podporou Ministerstva školství, mládeže a tělovýchovy - výzkumný záměr „Reprodukce a integrace společnosti“ (MSM0021622408) a s podporou grantového projektu Grantové agentury České republiky „Porody, asistovaná reprodukce a zacházení s embryi. Sociologická analýza současné reprodukční medicíny v ČR“ (GA404/11/0621). 
tak jak se odráží ve zdánlivě pragmatických volbách neplodných párů, je hlavním tématem tohoto textu. Skrze analýzu rozhovorů s neplodnými páry chci zjistit, jak sami s normami týkajícími se rodičovství pracují a zda je možné v jejich výpovědích identifikovat normativní posun ve vztahu k rodičovství ve smyslu jeho klesajícího významu v individuálním životě, který je považovaný za jednu z př́íčin nízké porodnosti v České republice (Rabušic 2001). Výpověd' těch, kteří aktuálně zvažují různé varianty rodičovství, jeho konkrétní podobu či rizika, která jej provázejí, nám umožní zjistit, jak jsou jednotlivá řešení neplodnosti - adopce, dárcovství a bezdětný život - definována a hierarchizována a jak je normativita rodičovství prožívána těmi, kteří o něj usilují.

\section{Metodologie}

Text je založen na kvalitativním výzkumu, data byla sbírána prostřednictvím hloubkových rozhovorů. Výzkumné rozhovory byly realizovány s 31 ženami a pěti muži ve věku od 25 do 44 let, kteří celkem reprezentovali 31 partnerských párů řešících neplodnost. Všichni, kromě jedné rozvedené konverzační partnerky (rozvod následoval po mnohaleté neúspěšné léčby neplodnosti), žili ve stabilním heterosexuálním vztahu.

V sedmi případech tyto páry řešily sekundární neplodnost, tedy problémy při početí druhého dítěte (z pohledu ženy, nebot' $\mathrm{v}$ těchto př́padech často usilovaly o početí s novým partnerem). Pět konverzačních partnerek bylo v době rozhovoru těhotných (tř́i otěhotněly přirozeně po delším období léčby, dvě díky léčbě). Jedna měla adoptivního potomka a tři měly dítě díky léčbě neplodnosti a potýkaly se s problémy při snaze o další těhotenství. Kontaktování účastníků výzkumu probíhalo třemi zpo̊soby: v rámci sociální sítě autorky výzkumu, skrze internetové servery o neplodnosti a technikou sněhové koule (každý aktér výzkumu byl požádán o zprostředkování nového kontaktu). Rozhovory probíhaly s muži i ženami odděleně, až na jednu výjimku, rozhovor s Albertem a Karolínou, který byl částečně rozhovorem společným.

Výzkumný rozhovor probíhal podle velmi obecného scénáře, který se proměňoval jak na základě analýzy předchozích rozhovorů, tak s ohledem na konkrétní výpověd' aktéra/ aktérky. V úvodu rozhovoru jsem konverzační partnerky a partnery požádala, aby co nejpodrobněji popsali svou cestu k rodičovství a všechny kroky, které na ní podnikli, až do dne rozhovoru. Následně jsem se snažila rozvíjet témata vzešlá z předchozí výpovědi a také témata nová, vnesená do rozhovoru mnou nebo mým konverzačním protějškem. Kombinace narativního př́stupu v první části rozhovoru a dotazování ve druhé části rozhovoru umožnila dát prostor samostatné interpretativní úloze aktérek/aktérů, a zároveň rozhovor korigovat $\mathrm{s}$ ohledem na nesrovnalosti nebo zajímavá témata vzešlá $\mathrm{z}$ jejich výpovědi a ve vztahu $\mathrm{k}$ cílům výzkumu.

Výzkum vycházel z interpretativistického paradigmatu, jeho cílem bylo získat autentický vhled do zkušenosti s neplodností a její léčbou a odpovědět na otázku, co pro člověka neplodnost znamená a jakým způsobem se na situaci, kdy nemůže naplnit své reprodukční plány, adaptuje. Cílem mé práce nebylo generovat zakotvenou teorii, nicméně využívám analytické postupy obecnějšího charakteru, které zakladatelé zakotvené teorie Strauss a Glaser navrhli (Glaser a Strauss 1967) a které se dobře osvědčují i při dalších typech kvalitativní 
analýzy. Za data považujeme „všechny stopy naší empirické práce“ (Konopásek 1997: 74), předmětem mé analýzy tedy byly doslovně přepsané záznamy 36 provedených rozhovorů (tedy výpovědí informátorů a otázek a reakcí výzkumnice), terénní poznámky, které vznikaly př́mo během rozhovorů a po jejich skončení, a analytické poznámky, kterých přibývalo $\mathrm{v}$ průběhu přepisů a analytické práce $\mathrm{s}$ přepisy rozhovorů.

Výsledky kvalitativní analýzy jsou v následujícím textu rozděleny do tematických celků, které reflektují kategorie vzešlé $\mathrm{z}$ dat. V zájmu plynulosti textu neuvádím u velmi krátkých citací (jednotlivá slova či sousloví) jméno konverzačního partnera nebo partnerky, delší citace jsou již jmény uvozeny.

\section{Vlastní versus cizí}

Ačkoli vzorce rozhodování se o krocích vedoucích k rodičovství u neplodných párů byly různorodé, $\mathrm{v}$ jednom se neplodné páry shodly - asistovanou reprodukci využívající vlastní pohlavní buňky (tedy inseminaci nebo klasické umělé oplodnění) přijímali jako primární a neproblematické řešení neplodnosti. Přestože od zjištění problému do akceptování léčby často uplynul nějaký čas smiřování se se situací a s nutností lékařské intervence, souhlas $\mathrm{s}$ asistovanou reprodukcí popisovali jako automatickou reakci na to, že s jejich plodností něco není v pořádku, jako řešení ve smyslu odstranění problému. Touha po vlastním dítěti, kvưli jehož početí je nutné překonat i nemalé překážky, je naturalizována, je to „takový základní pud člověka“, jak řekla konverzační partnerka Sylvie, „člověk v sobě má geneticky uložený, že chce ty děti, aby byly jakoby jeho“. Naturalizace touhy po biologickém rodičovství slouží v její výpovědi zároveň jako legitimizace všech kroků, které s cílem počít potomka podniká.

„Jsme socializováni k tomu mít biologické dítě,“ uvádí v kontrastu s výpovědí Sylvie van den Akker (2001). V rozhovorech projevovaná a naturalizovaná preference biologického rodičovství (i za cenu využití náročných technik asistované reprodukce) před adopcí ukazuje na primárnost pokrevního pouta v rámci současné západní konstrukce rodičovství, které zdůrazňuje řada autorů a autorek. Pokrevní spř́izněnost, které je připisován mystický a transcendentální charakter, je považována za hlavní zdroj rodičovského pouta a lásky (Miall 1994, Letherby 2002, Webb a Daniluk 1999)² a adoptivní rodičovství je coby rodičovství nebiologické vnímáno jako druhořadé a patogenní (Wegar 2000, Lorber 1989) a jako vysoce rizikové, zatímco rizika spojovaná s asistovanou reprodukcí se opomíjejí (Hašková a Zamykalová 2006).

2 Nic na tom nemění ani stále častější volání sociologů po přehodnocení strukturálních a funkcionalistických př́stupů ke studiu rodinného života a po př́íklonu $\mathrm{k}$ behaviorálnímu př́istupu, který se zaměřuje spíše než na formální strukturu rodiny na aktuální rodinné chování společnosti a který bude lépe reflektovat proměnlivost a různorodost dnešních rodinných forem (van den Akker 2001, Bernardes 1996). Rodina založená na formální struktuře a tvořená ,jádrem“ heterosexuálního rodičovského páru a jejich biologických potomků není podle těchto autorů statisticky častější ani reálnější nebo přirozenější než jiné formy rodinného uspořádání.

3 Není tomu tak ale všude, jako například u afroamerických rodin; antropologové rovněž popsali mnoho nezápadních společností, kde je nebiologické př́buzenství jako adopce běžným a nestigmatizovaným typem utváření rodiny (Wegar 2000). 
Výjimkou s ohledem na volbu řešení neplodnosti byla konverzační partnerka Klára. S manželem hned po první konzultaci s lékařem odmítli nabídnuté řešení neplodnosti s poukazem na svou víru a na etickou spornost takových postupů. Rozhodli se, že pro jiné páry automatickou fázi ve snaze o rodičovství vynechají a dají přednost adopci.

Bavili jsme se o tom s bratrem a on ř́ḱkal, že bysme se do toho namočili, a mohli bysme se dostat do nepř́iemných situací, že bychom se nerozhodovali jenom jestli IVF $^{4}$ ano nebo ne, ale kolik nechat vzniknout embryí, kolik transferovat, kolik zamrazit, a to by se asi neslučovalo s tou morálkou, s naším přesvědčením. [...] Takže tohle byla taková věcná poznámka, kdy jsem si uvědomila, že to není hra, že to není šmudlání na miskách, že jde o reálný životy, pro nás to nebyl materiál, jak to nazývali oni, pro nás to byl člověk od spojení dvou buněk, takže to byla věc dost závažná a takový krajní zahrávání si.

Rozhodování se o řešení neplodnosti a definice rizik spojených s jednotlivými cestami $\mathrm{k}$ rodičovství ukazují, že definice problému a řešení v pojmech medicíny jsou pro neplodné páry primární. Rámování neplodnosti, jejího řešení, ale i souvisejících rizik medicínskými pojmy, jako je nemoc-léčba-buňky-krevní skupina je snadno akceptovatelné, srozumitelné, jasně vymezuje úlohy jednotlivých účastníků procesu. „Síla medikalizace tkví v její všudypř́ítomnosti,“ píše Lebner (2000: 372). Expanze medicínských definic ovlivnila to, že pojímáme různé situace $\mathrm{v}$ životě primárně v medicínských termínech (Illich 2000). Příklon k medicínskému řešení z neplodnosti zároveň částečně smazává stigma: neplodní jsou v lékařském kontextu nemocnými, kteří za svou nemoc nemohou, a dávají najevo svou připravenost podstoupit léčbu, která jejich problém vyřeší.

Asistovaná reprodukce využívající dárce nebo dárkyně nebo adopce dítěte ${ }^{5}$ jsou zkoumanými páry považovány za mnohem problematičtější způsoby řešení neplodnosti než asistovaná reprodukce využívající pohlavní buňky budoucích rodičů. Konverzační partnerky a partneři popisovali rozhodování o dárcovských buňkách v reprodukci jako obtížné a zásadní, spojovali je s většími dilematy a kompromisy a odsouvali až na dobu, kdy postupy klasické asistované reprodukce selžou. Pro některé páry jsou tyto postupy už za hranicí toho, co jsou ochotny pro rodičovství udělat.

Jak adopce, tak asistovaná reprodukce s využitím dárců znamenají částečnou nebo úplnou ztrátu genetické vazby rodičů k dítěti. Důraz na genetickou vazbu k potomkovi je připisován (a to jak v rámci interpretací konverzačních partnerek, tak v sociálněvědecké debatě týkající se rodičovství či maskulinity) především mužům a vnímán jako součást mužské identity, jako „mužská hrdost“. Muži i ženy však o ztrátě genetické vazby k dítěti mluvili velmi

In vitro fertilisation

Srovnání hypotetických postojů obecné populace k léčbě neplodnosti, zjištovaných pomocí kvantitativních metod, a reálného jednání neplodných párů např́íklad v akceptaci adopce jako řešení neplodnosti ukazuje na významné rozdíly - zatímco obecná populace postavila adopci jako zvažované řešení neplodnosti těsně za řešení medicínské (Slepičková 2007), pro neplodné páry je adopce nejčastěji řešením následujícím po vyčerpání všech možností léčby, a zdaleka ne univerzálně akceptovatelným. Tyto rozdíly odrážejí efekt sociální žádoucnosti odpovědí, které se týkají adopce, ale také vývoj v nahlížení na řešení neplodnosti, které je radikálně odlišné, je-li s touto diagnózou pár skutečně konfrontován. 
podobně: zdůrazňovali ztrátu možnosti vidět $\mathrm{v}$ dítěti sám sebe (a to jak vzhledově, tak povahově), která je popisována jako esence rodičovství; strach z toho, co se z dítěte ,vylíhne“, jak poznamenal jeden konverzační partner; nejistotu ohledně toho, jak dárce či biologičtí rodiče dítěte vypadají. Akceptovat adopci nebo asistovanou reprodukci s dárcovskými buňkami znamená zásadně ustoupit z původních představ o rodičovství jako o prodloužení existence skrze geneticky vlastní dítě.

Při zvažování adopce či asistované reprodukce s dárcovskými buňkami se na přetřes dostává klasické dilema „př́roda vs. kultura“, zde spíše v podobě „geny vs. výchova“. Vstupem „cizích“ genů do rodičovství je narušena určitá jistota v rodičovství, která je spatřována $\mathrm{v}$ genetické spřízněnosti rodičů a dítěte, $\mathrm{v}$ tom, že dítě vyrůstá do podoby a povahy svých rodičů. Zatímco s asistovanou reprodukcí s použitím vlastních pohlavních buněk žádná rizika spojována nejsou, výpovědím o adopci či dárcovských buňkách dominují témata nejistoty a rizik, která jsou u těchto dvou řešení neplodnosti vnímána značně rozdílně. Prostřednictvím přisuzování různých typů rizika těmto dvěma typům rodičovství konverzační partneři konstruovali „odlišnost“ či „,cizost“ (v príípadě adopce) a ,podobnost“ (v případě asistované reprodukce spojené s dárcovskými buňkami) př́padného potomka.

„Cizí geny“ představují riziko biologické, nebot' mohou být zdrojem neznámých chorob a dispozic k nim či komplikací při nutnosti darovat dítěti orgán atd. Zároveň jsou cizí geny, $\mathrm{s}$ odkazem ke skutečným prŕběhům adoptivních dětí z př́ibuzenstva či okolíb, ztotožňovány s neznámými a zároveň velkými riziky, která nemají biologickou či medicínskou povahu. Jedná se především o rizika výchovná, která nemusí být zpočátku zjevná, ale mohou v jednu chvíli, nejčastěji v dospívání, vybuchnout jako časovaná bomba nebo se jako bumerang obrátit proti rodičům. Zatímco s použitím dárcovských buněk při asistované reprodukci je spojováno riziko biologického nesdílení, které se projeví zase v kontextech biologických (nemožnost dárcovství orgánu při nutnosti transplantace, náhodné zjištění neodpovídající krevní skupiny, výrazně jiná fyzická podoba potomka), s adopcí je asociováno riziko problematické výchovy a komplikovaného vztahu dítěte a rodičů. I dárcovství embrya je tak pro mnoho neplodných párů přijatelnější než adopce, přestože $\mathrm{v}$ obou př́ípadech genetická spř́izněnost s rodiči zcela chybí.

Tato preference je konverzačními partnery a partnerkami vysvětlována jiným typem genů, které vstupují do hry: dárci jsou určitým způsobem a na základě konkrétních požadavků (např́iklad na vzdělání) vybraní jedinci - u dárcovských embryí se jedná o páry, které se léčily pro neplodnost. Lidé, jejichž děti se ocitají v dětském domově, jsou neplodným párům, kteří o rodičovství usilují, značně vzdáleni. Tato jinakost se týká i samotných dětí, je předpokládaná do budoucna, ale zjevná již v okamžiku adopce. V př́ípadě dárcovství pohlavních buněk na rozdíl od adopce pár navíc není ochuzen o prožitek těhotenství, které je určitým fyzickým přisvojením si cizích genů - cizí geny jsou přivlastněny a jejich nebezpečnost zmírněna tím, že vyrůstají v děloze budoucí matky a že budoucí matka je porodí. Získává tak aktivní podíl na růstu budoucího života.

6 Je příznačné, že „skutečné příběhy“ dětí počatých díky dárcovským buňkám nebo darovanému embryu nikdo nezná. 
Uvažovala jsem nad adopcí, ale říkala jsem si zase, takhle bych to dítě aspoň nosila, a když to dítě nosím, tak mi doktor říkal, že jsem padesátiprocentní matka. Geny to mít nebude, mám strach, že se jednou něco stane, že budou tomu dítěti muset něco transplantovat, a já vlastně nebudu moct tomu dítěti něco darovat, když nebudu genetická matka. Ale ten vztah k tomu dítěti si určitě utvořím, když ho budu nosit... To určitě.

(Veronika, připravující se na IVF s použitím dárcovských vajíček)

Těhotenství také zmírňuje další riziko spojované s adopcí - obtížnost navázání vztahu $\mathrm{k}$ dítěti, protože se předpokládá, že vztah $\mathrm{k}$ byt' biologicky nevlastnímu potomkovi je díky těhotenství přirozený, zprostředkovaný v procesu přirozeného zrání k rodičovství a navozený hormony.

Důraz na geny, jejich kvalitu a potenciální rizikovost ve výpovědích neplodných mužů a žen poukazuje na rozvíjející se proces geneticizace coby rutinního užívání genetických technologií (Lebner 2000), které významně ovlivňuje naši zkušenost s tělem, zdravím a nemocí a reprodukcí (Conrad 2007). Geneticizace je součástí procesu medikalizace a přináší nové způsoby diagnostiky a léčby chorob, ale také nové způsoby kategorizování fyzických stavů a zdravotních rizik, které výrazně ovlivňují také laický diskurz. Zájem o kvalitu genů a genetické screeningy se stávají součástí zodpovědného chování ke zdraví a odrážejí představu, že dokonale něco (v tomto př́padě genom) prozkoumat znamená kontrolovat eventuální rizika (Lippman 1998). Geny hrají stále důležitější roli v určování příbuzenství a důraz na ně začíná nahrazovat důraz na pokrevní vazbu (Lebner 2000).

Tak jako je adopce a asistovaná reprodukce využívající dárce spojována s jinými typy rizika, realizace obou procedur má značně odlišnou podobu, která podtrhuje jejich různý status a odlišnou míru stigmatizace: Zatímco asistovaná reprodukce používající dárcovské pohlavní buňky je rutinně praktikovanou a snadno a rychle dostupnou medicínskou procedurou (obzvlášt' to platí v prŕípadě embrya nebo spermie), adopci provází dlouhý, často několikaletý proces administrativy, tréninku, př́prav a prověřování budoucích rodičů. Souhlasit s asistovanou reprodukcí znamená nechat proniknout medicínu a dárcovské buňky do intimní sféry partnerského života, souhlas s adopcí je akceptací toho, že do soukromého života páru vniká byrokratický aparát, úřady, vyšetřující psychologové, neprrímo také biologičtí rodiče dítěte atd. Vztah rodičů $\mathrm{k}$ adoptivnímu dítěti je zprostředkováván skrze úředníky, klíčovou institucí je v prrípadě dárcovských buněk nebo embrya medicína. Přijetí cizích genů v podobě jednotlivých buněk, patřičně ošetřených a aplikovaných za využití moderních technologií, je akceptovatelnější než přijetí již narozeného dítěte. ${ }^{7}$ Konverzační partnerce Monice v tomto procesu pomohlo přirovnání situace ke smrtelné nemoci, kterou řeší jen přijetí transplantovaného orgánu - tedy vyspělá medicína. V rozhovoru popisovala, že přijmout cizí genetický materiál pro ni bylo představitelné jen tehdy, měl-li mít podobu jednotlivých buněk - spermií.

\footnotetext{
7 I přes vysoký podíl dětí v ústavní péči v České republice je jen málo dětí dostupných $\mathrm{k}$ adopci a ještě méně těch, která odpovídají požadavkům adoptivních rodičů - většina $\mathrm{z}$ nich chce dítě co nejmenší, zdravé a světlé pleti, tedy co nejpodobnější dítěti, které - jak předpokládají - by sami zplodili.
} 
Manžel se s tím srovnal docela rychle, mně to trvalo dýl. Já jsem se snažila to v sobě nějakým způsobem srovnat, že kdyby byl člověk nemocnej a věděl, že jeho život závisí na tom, aby přijmul cizí játra, tak to taky udělá.

Namísto jednoduchého úkonu inseminace, který by pro její tělo znamenal nežádoucí kontakt s částí cizího těla, Monika trvala na provedení mnohem náročnějšího a invazivnějšího umělého oplodnění, přestože to vzhledem k diagnóze nebylo nutné. „Cizost“ genů a odpor ke konkrétnímu materiálu jsou zmírněny jejich průchodem přes lékařskou laboratoř.

$\mathrm{Na}$ rozdíl od adopce, která počítá se spoluprací a zapojením obou partnerů, navíc léčba vyžaduje aktivnější př́stup žen. Vyhovuje tak obvyklému rozložení iniciativy $\mathrm{v}$ párech léčících se pro neplodnost, v nichž muž akceptuje či preferuje svou pasivní roli, nebo není ochoten se řešením situace zabývat (Slepičková 2011). Právě odpor svých partnerů k jednání $\mathrm{s}$ úřady a k narušování soukromí ze strany byrokratických institucí označují konverzační partnerky za hlavní důvod, proč jejich protějšky adopci odmítají. Lékaře a lékařky má většina lidí ve větší úctě než úředníky a úřednice, ale mužský odpor ke styku s lékaři či k vyšetřování intimních částí těla je stejně tak přijímán jako legitimní zdůvodnění pro odmítání podílu na léčbě. Spíše než o nesouhlas s konkrétními postupy jde tedy ze strany mužů (v případě jejich odporu) o odmítání adopce jako takové, nebo o odmítání jakékoli aktivity ve vztahu $\mathrm{k}$ řešení neplodnosti.

$\mathrm{Z}$ důrazu na odlišnost genů adoptovaného dítěte ve srovnání s ,podobností“ genů dárce je zřejmé, že důležitou roli v rozhodování mezi adopcí a asistovanou reprodukcí má ne/viditelnost povahy takového rodičovství pro okolí. Zatímco adopci zaznamená každý a každý v ní bude vidět neplodnost jako hlavní motiv, povahu těhotenství vzniklého díky dárcovským buňkám není nutné okolí, nejbližším příbuzným ani samotnému dítěti odhalovat (mnozí ani nemusí vědět, že taková varianta řešení neplodnosti existuje). V př́ípadě dárcovství navíc i praxe zařizení provádějících asistovanou reprodukci nahrává tomu, aby bylo co nejlepší imitací přirozeného početí, a tím jen potvrzuje důležitost genetických vazeb pro rodičovství - dárcovské embryo nebo spermie jsou vybírány podle fyzické podoby (výšky, barvy vlasů a očí) a krevní skupiny budoucích rodičů, což zajištuje fyzickou, viditelnou podobu dítěte a rodičů, na kterou je neplodnými páry kladen důraz a která je navázána na další aspekty podobnosti (povahové) a na rozlišování mezi vlastním a cizím. Adopce díky tomu, že je viditelná pro okolí, přitahuje nechtěnou a potenciálně stigmatizující pozornost nejen k samotnému adoptivnímu dítěti, ale i k neplodnosti jeho rodičů. Těhotenství je cílem léčby neplodnosti a důkazem jejího úspěchu, funguje jako jasný znak toho, že pár není neplodný, adopce ukazuje pravý opak. Přistoupení na adopci více než pokračování v léčbě, byt's dárcovskými buňkami, evokuje prohru, rezignaci a neúspěch, kromě stigmatu neplodnosti přináší stigma neúspěšné léčby a nelegitimity potomků.

V konstrukci rodičovské vazby neplodnými páry jsou, jak vyplývá z výzkumných rozhovorů, klíčové tři momenty - autorita medicíny, která je klíčovou institucí pro zkušenost neplodnosti, odkaz k síle genů coby konceptu legitimizujícímu jak usilování o rodičovství, tak odmítání jiné než genetické vazby k potomkům, a také způsoby, jakým jsou geny použivány $\mathrm{k}$ budování hranic mezi spolehlivým a rizikovým, cizím a vlastním, odlišným a podobným. Ze způsobů, jakými konverzační partneři a partnerky s těmito hranicemi pracovali, je zjevný také důraz na viditelnost rodičovských vazeb, který potvrzuje primárnost 
genů jako určující substance pro př́ibuzenství a také jejich symbolický význam. Hierarchie rizik, spojovaných s různými typy rodičovství, tak jak je ve svém výzkumu popsaly Hašková a Zamykalová (2006), tak výzkumné rozhovory zdánlivě potvrzují, za určitých okolností je ale pyramida rizik, na jejímž vrcholu stojí adopce (spolu s ne-rodičovstvím), obrácena, jak uvidíme v následující části.

\section{Přirozenost a jistota $v$ adopci}

Postoje k různým typům rodičovství nejsou u neplodných párů stálé, často se mění s délkou času stráveného pokusy o řešení neplodnosti, a také s tím, jakému řešení je v momentální situaci připisována největší (nebo jediná) šance na úspěch. To, co dříve nepřipadalo v úvahu, je tváŕí v tváŕ neúspěchu léčby a zvyšujícímu se věku přijatelnou nebo alespoň zvažovanou variantou, jak to ukazuje výpověd' Mirka, týkající se úvah o přijetí dárcovského embrya, nebo Věry, která mluví o adopci.

Kdyby ses mě třeba zeptala před několika lety, tak by ten názor byl asi jiný než dneska. Ale člověka ovlivňují ty okolnosti, a naším cílem je mít nějakého potomka, asi ne za každou cenu, ale jsme ochotni pro to udělat hodně. Byl bych ochoten to přijmout nebo se $s$ tím nějak vyrovnat.

Já jsem si to nikdy nepřipouštěla, vůbec, pro mě slovo adopce bylo kategoricky nepřijatelný, nikdy. No ale jak člověk asi stárne a má míň a míň času, tak to nezavrhuju úplně. Nemůžu říct, že bych se na to ptala nebo brala to jako řešení, když se to nepovede, to ne. Ale i adopce je pro mě možná přijatelné řešení, nebo možné [důraz na slovo možné] řešení, přijatelné ne.

Pro většinu konverzačních partnerů a partnerek je to právě tlak ubíhajícího času a zužujících se možností léčby, co je přivedlo k akceptaci adopce - jen jediná konverzační partnerka, Dana, uvažovala se svým manželem o adopci (jako o způsobu rozšíření rodiny) dříve než zjistili, že počít vlastní dítě pro ně bude problém.

Nejpozitivnější vztah $\mathrm{k}$ adopci v rozhovoru projevovaly konverzační partnerky, které jí jsou nejblíže a které zažily zklamání z dlouhodobé léčby neplodnosti: Dana, která po několika letech léčby spolu s manželem vychovává adoptované dítě, a také Mirka, která na adopci po několika letech léčby čeká. S manželem už prošli př́ípravným kurzem pro budoucí adoptivní rodiče a všemi nezbytnými vyšetřeními. Na rozdíl od jiných konverzačních partnerek a partnerů, kteří tyto byrokratické procedury hodnotí jako ponižující a někdy i nepřijatelné, aniž by s nimi měli vlastní zkušenost, Mirka si z celého procesu odnesla pozitivní zážitky a popisuje jej jako zkušenost, která ji zbavila méněcennosti a nejistoty ve vztahu k rodičovství, také díky setkání s lidmi s podobným problémem.

My jsme se tam seznámili s úplně stejnýma lidma, jako jsme my, lidi, co je jim přes třicet a jsou aktivní a cestujou a jsou sympatický a furt jsme tam řešili tu adopci, neřešila se neplodnost. A sprátelili jsme se tam s těma párama a došli jsme na oběd a pořád jsme se bavili tak nějak obecně. A když jsme došli do tý posluchárny, tak posledních pět minut najednou z nás začlo padat to o problémech s tou neplodností, a jak vy to máte a co vy. Ta neplodnost tam byla úplně všude příčinou těch žádostí o adopci. A bylo to poprvý, kdy jsem měla pocit, že se o tom můžeme s někým bavit jako pár, že to bylo hrozně př́ijemný v tom, že jsem tam viděla sympatický normální lidi, že 
se člověk trápí, v čem je jinej nebo špatnej, jako ne trápí, ale pořád to v sobě má, a ted’ tam byli takoví sympatičtí lidi.

Dana hodnotí svou zkušenost s adopcí natolik pozitivně (ř́ká, že takové dítě, jako je jejich adoptované, by se jim s manželem ani „nepovedlo“), že i v rámci úvah o druhém dítěti je jí adopce bližší než další léčba, přestože ještě nevyčerpala pokusy hrazené pojišstovnou. Pokračování v léčbě by pro ni bylo spíše velkou investici s nejistým výsledkem a zničujícím dopadem na její tělo a psychiku.

V př́ípadě Martina měl na pozitivní postoj k adopci vliv jeho nevlastní otec, který jej vychoval a ke kterému měl dobrý vztah. Martin zdůrazňuje vztahový aspekt rodičovství, který klade nad biologickou spř́żzěnost.

Myslím si, že není důležitý ten biologický otec, ale ta láska, co tomu dítěti dáváš, že se o něj každý den staráš, že se k němu vstává, že se člověk vrací rád z práce, aby ho zastihl, ještě než jde spát, aby si ho vykoupal, to jsou věci, pro který asi stojí za to žít. Že to prostě není takový to, že se dítěti dá ovladač od televize.

Právě pozitivní zkušenost s navázáním intenzivního vztahu (at' už z pozice dítěte nebo dospělého) mezi dítětem a dospělým (např́íklad ve vztahu dítě a nevlastní rodič nebo vychovatelka a dítě) zmiňovali i ostatní konverzační partneři a partnerky jako něco, co jim pomáhá vyrovnat se s faktem, že jejich dítě nebude biologicky vlastní, nebo jako důvod toho, že odmítají řešení neplodnosti skrze dárcovské buňky a dávají př̌ednost adopci.

Pro mnohé konverzační partnerky a některé konverzační partnery byla adopce především pojistkou pro př́pad, že by léčba byla neúspěšná a hrozil by jim bezdětný život. Často se o ni začali zajímat už během procesu léčby. Adopce, se všemi zmíněnými riziky a negativy, byla vnímána především jako jistá cesta k dítěti ve srovnání s asistovanou reprodukcí, jejíž úspěch nelze zaručit. Adopce na rozdíl od asistované reprodukce skýtá „reálnou možnost úspěchu“, nejsou s ní spojena zdravotní rizika a nežádoucí vedlejší účinky, nevzbuzuje otázky ohledně etičnosti a ve srovnání s využitím dárcovských buněk je také „spravedlivějšši“, protože dítě má stejnou vazbu k oběma adoptivním rodičům. Mirka adopci popisuje jako zcela přirozenou - ve všech historických dobách podle ní bylo běžné, že se opuštěných a osiřelých dětí ujímaly bezdětné páry nebo jiné rodiny.

Pohled na adopci jako na jistou cestu k dítěti zdůrazňovaly, často přes nesouhlas či váhání svých partnerů, především ženy. Ženy si obvykle př́ly podat žádost o adopci už v průběhu léčby a označovaly reálné vyhlídky na adoptované dítě za podstatnou psychickou vzpruhu, za důležitý záložní plán, který jim pomohl překonat pocity beznaděje z neúspěšné léčby. Jejich partneři často zastávali jiné stanovisko a diskusi o adopci odsouvali na období po př́padném neúspěšném absolvování několika pokusů o umělé oplodnění nebo rovnou dávali najevo svůj - nelogicky zdůvodněný - nesouhlas s plánem adoptovat, podobně jako Albert.

Já jsem zas takovej, když nad tím budu přemýšlet, tak do jaký doby člověk dneska ty děti přivede. Kdybychom měli svoje, tak ne, ale kdyby to nešlo, tak to nebudu lámat přes koleno. $V$ dnešní době je to takový zvláštní. Nevím, je jiná doba. Za nás to bylo jiný.

Že je adopce sporným a mezi partnery obtížně nebo málo diskutovaným tématem, je zřejmé také z porovnání výpovědí partnerů. Zatímco Jiřina o adopci mluví jako o jedné 
z variant řešení neplodnosti, se kterou s manželem počítají, její muž říká, že s adopcí nesouhlasí a dal by před ní přednost životu bez dětí. Podobné rozpory jsou patrné ve společné výpovědi Alberta a Karolíny. Karolína nejprve mluví o adopci s nadšením (po prvním neúspěšném pokusu IVF dokonce byla na úřadě pro potřebné formuláře), po nesouhlasných reakcích partnera svůj jednoznačný postoj zmírňuje a zdůrazňuje problematičnost celého procesu. Tato situace se během rozhovoru několikrát opakovala

Albert: My ted’ka máme ty psy, takže když nebudou děti, tak budou psi. Budeme mít pět psů a bude.

Výzkumnice: Tak to vidíte...?

Albert: I tak se to dá brát. Tak to je ještě předčasný takový věci, já to neřeším dopředu.

Karolína: Ne, je to obrovský, obrovský jako... S tou adopcí jako...

Albert: Karolína to začala řešit moc brzy, tu adopci, bych řekl, na mě.

Karolína: No protože já jsem měla jít na tu operaci a potřebovala jsem se jakoby od něčeho odrazit. Bud'to to prostě vyjde nebo ne, tak člověk potřebuje nějakou únikovou cestu. Takže jsem si jakoby tím pomohla, hodně mi to pomohlo.

Albert: Tak já jsem jí to nebral, já jsem ji nechal v tom, že jakože jo, že se to stejně časem...

Karolína: Jo, stejně jsme si museli vyřešit byt a časem třeba už i si sami přicházíme na nějaký věci, že... Jasný, mít toho svýho.

Kritikové reprodukčních technologií zdůrazňují, že to byl právě jejich rozvoj, mediální popularita a image všemocnosti, které odsunuly adopci jako způsob řešení neplodnosti na poslední místo, zdůraznily její stigmatizaci a posílily imperativ biologického rodičovství (Miall 1989, Lorber 1989, Wegar 2000). Jen ti, kteří využijí veškeré dostupné lékařské prostředky k početí dítěte, se považují za skutečně odhodlané a správné rodiče a zasluhují si nálepku nedobrovolně bezdětných, která je zbavuje stigmatu a viny, spojovaných s dobrovolnou bezdětností (Hašková a Zamykalová 2006).

Výzkumné rozhovory ukázaly, že adopce je neplodnými muži a ženami vnímána jako nouzové řešení spíše než pozitivní volba, jako pojistka proti bezdětnosti. Za určitých okolností může být adopce definována jako zdroj jistoty. K této definici vede především dlouhodobá bezprostřední zkušenost s vyčerpávající léčbou s nejistým výsledkem, jak ukázala přiznaná proměnlivost postojů $\mathrm{k}$ adopci $\mathrm{v}$ čase. Ta je $\mathrm{v}$ mnohem větší míře zažívána ženami než muži, což je dáno jednak formální úpravou přístupu k asistované reprodukci v ČR, který je limitován věkem ženy, jednak věkovými normami pro rodičovství, které výrazněji apelují na ženy než na muže (Bailey 1999, Sevón 2005, Hašková a Zamykalová 2006, Vidovičová a Gregorová 2007). Vysvětluje to tu skutečnost, že ženy jsou častěji než muži zastánkyněmi adopce jako řešení neplodnosti, zatímco jejich partneři zdůrazňují rizikovost procesu adopce a rozhodování o ní se vyhýbají, nebo jej odsouvají. Nemají takovou potřebu hledat v nekonečném usilování o rodičovství světlý bod či ,únikovou cestu“, protože se jich fyzicky netýká. Jsou ochotnější rezignovat na rodičovství jako takové, protože pro jejich identitu nehraje takovou roli. Zároveň potřebují k vyrovnání se s diagnózou nebo prŕpadnou rezignací na biologické rodičovství více času než jejich partnerky a tento čas mají navíc díky neomezeným reprodukčním schopnostem, na rozdíl od žen, $\mathrm{k}$ dispozici. K podobným závěrům 
došla i Mason (1993); její neplodní konverzační partneři zdůrazňovali potřebu delšího času na to vyrovnat se s diagnózou a rozhodnout o dalším postupu a zejména o tom, zda je pro ně důležitější rodičovství biologické nebo sociální. Rozhodování žen tedy může ovlivnit určitý časový náskok s vyrovnáváním se s bezdětností, a také jimi vnímaný tlak času, který na muže tolik nepůsobí.

Adopce, na rozdíl od dárcovských metod asistované reprodukce, znamená navíc přiznat před okolím vlastní neúspěch ve snaze o početí potomka, a tedy znásobené stigma - absence biologické vazby v rodičovství a neplodnosti. Skutečnost, že muži adopci přijímají obtížněji, nemusí tedy vyplývat z jejich větší fixace na biologické rodičovství, ale - kromě výše zmíněného odlišného vnímání času v léčbě neplodnosti - z odlišného stigmatu, které pro ně neplodnost ve srovnání s ženami má.

\section{Vajíčko nebo spermie aneb Každá ženská chce mít dítě svého chlapa}

V některých prŕípadech diagnóza indikuje, zda je pro léčbu nutné prrijmout dárcovské spermie nebo vajíčko, u některých příčin neplodnosti (týká se to naprríklad imunologických poruch) je možné vybrat si, která z pohlavních buněk bude pocházet od dárce a která od jednoho $\mathrm{z}$ budoucích rodičů. Pokud by hlavním motivem výběru byla jednoduchá a rychlá cesta k potomkovi sdílejícímu genetickou informaci alespoň s jedním členem rodičovského páru, darované vajíčko by nikdo nevolil, protože se jedná o mnohem dražší, delší a pro dárkyni i př́ijemkyni fyzicky náročnější proceduru, než je využití darované spermie. ${ }^{8}$ Nelehké rozhodování v této situaci je ale ukázkou toho, jak různými obsahy je naplňováno rodičovství u jednotlivých párů a také u mužů a žen obecně.

V př́padech, kdy je nutné volit, zda dárcovské buňky nahradí buňky budoucího otce nebo matky, jsou to častěji konverzační partnerky než jejich protějšky nebo konverzační partneři samotní, kdo deklaruje ochotu se genetické vazby k dítěti vzdát. Ženy často uvádějí, že léčba užívající darovaných spermií je pro ně nepřijatelná, protože partnera si vybraly také jako vhodného biologického otce svých potomků a chtějí mít děti, které budou biologicky jeho a budou mu fyzicky i vlastnostmi podobné. „Každá ženská chce dítě svého chlapa“, tlumočil svou představu o postojích své partnerky Albert. Někdy je preference dárcovských vajíček před spermiemi popisována jako ústupek ze strany ženy, která vychází vstř́ic manželovu přání nebo respektuje jeho ,právo veta“, prŕípadně si myslí, že partner si vlastní děti „zaslouži“", víc mu na tom záleží nebo že jeho geny by měly být reprodukovány vzhledem k jeho dobrým vlastnostem a povahovým rysům. Stejný postoj jako partneři konverzačních

Dárcovské spermie jsou na klinikách dobře dostupné a vybírají se mimo jiné podle fyzické podobnosti a krevní skupiny dárce a budoucího otce. Zákrok se může odehrát jako finančně nenáročná a pro tělo ženy šetrná inseminace. Na darovaná vajíčka se naproti tomu čeká několik měsíců (často je nutné pro posunutí se $\mathrm{v}$ pořadníku přivést na kliniku nějakou dárkyni, ale protože je dárcovství anonymní, vajíčko dostává žena od jiné dárkyně než od té, kterou přivedla) a je nutné pro jejich použití provést umělé oplodnění a hormonálně stimulovat dárkyni i př́ijemkyni - výběr dárkyně podle výšky nebo barvy vlasů budoucí matky není v praxi př́liš realizovatelný, protože dárkyň je velmi málo. Dárkyně navíc dostává finanční kompenzaci jako úhradu nákladů spojených $\mathrm{s}$ dárcovstvím. 
partnerek ve vztahu ke své ženě projevil i manžel konverzační partnerky Dity; ona sama přitom pochybovala o tom, zda by stejně automaticky preferovala biologické buňky svého muže před svými.

Primární, biologická a tělesná vazba $\mathrm{k}$ dítěti, kterou by žena mohla při přijetí dárcovských vajíček postrádat a která vystupuje jako základ vztahu k dítěti, je považována za nahraditelnou zkušeností těhotenství. Díky těhotenství a porodu se z dítěte ve vztahu k ženě stává dítě „vlastni“", stejně jako se dítě stává „vlastním“ dítětem muže skrze genetickou spřízněnost. „Co si porodím, to je moje,“ ‘rekla konverzační partnerka Lucie. Těhotenství je považováno za unikátní zkušenost, navázání privilegovaného vztahu k dítěti, který - i bez genetického podílu ženy - funguje sám o sobě, nebot' je zprostředkován tělem, krví, hormony. Tato vazba je o to pevnější, že je navazována dlouhodobě, v průběhu celého těhotenství jako období příprav a čekání. Rodičovství dosažené díky dárcovskému vajíčku je tak vnímáno jako spravedlivější, nebot' uchovává biologický podíl na něm oběma partnerům. ${ }^{9}$ Konverzační partnerka Mirka uvažovala o a/symetrii takového uspořádání následovně: ,...opravdu já bych se cejtila jako matka tak jako tak, i když by to vajíčko moje nebylo... Jako že by byl jistej ten otec, že je to jakoby víc, než když je jistá jenom matka.“

Výpověd’ Mirky zároveň ale naznačuje, že ženami deklarovaná ochota vzdát se svého genetického podílu na rodičovství a „nahradit jej“ zkušeností těhotenství a porodu může mít za prričinu také strach $\mathrm{z}$ toho, že vyloučení podílu partnera na reprodukci by mohlo ohrozit partnerský vztah nebo ochotu partnera k rodičovství obecně. Mužova genetická vazba k potomkovi je proto významnější (,,je to jakoby víc“") než ženina. Mirčin původní důraz na to, že její partner je sebevědomý člověk, který by unesl různé varianty řešení neplodnosti včetně využití dárcovských spermií, se v průběhu rozhovoru a zvažování různých variant mění v pochybnosti nad touto možností.

U tý neplodnosti to je ještě o tom, že člověk podvědomě cítí, že někde jinde by to mohlo zafungovat, že mám strach, aby to nechtěl zkusit ještě někde jinde. Ona jako je ještě jedna věc, to že je problém u něho se mnou, ještě nemusí znamenat, že je problém u něho s někým úplně jiným. Takže aby neměl fakt jako pocit, že by to měl vyzkoušet jinde, to bych možná měla strach vo to větší.

Rezignace na vlastní genetický podíl na rodičovství může být pro ženy rozhodnutím, které vtahuje jejich partnera $-\mathrm{z}$ rodičovství $\mathrm{v}$ důsledku neplodnosti potenciálně vyloučeného - do hry a posiluje jeho jinak problematickou angažovanost ve vztahu k léčbě, budoucímu potomkovi a také vazbu k partnerce, bude-li tou, která se stane matkou jeho dítěte. Relativně snadný a neproblematický ústupek je tak možná přejímáním či anticipací postojů partnera

9 Ve výzkumu náhradního mateřství popisuje podobný důraz na „spravedlnost“ rodičovství Ragoné (1997). Autorku výzkumu překvapilo, že páry obvykle nepodstupují test otcovství po narození dítěte náhradní matce, tak aby si byly jisty, že biologickým otcem dítěte je skutečně jeho budoucí otec (test otcovství je přitom součástí smluv o náhradním mateřství - dokud nepotvrdí otcovství budoucího otce, nemusí pár náhradní matce vyplatit její odměnu). Podle Ragoné se tím nastoluje spravedlnost v rodičovském podílu muže i ženy z rodičovského páru - otcovství není prokázané, přesto pár přijímá dítě za své a potvrzuje tak, že otcovství je sociálním konstruktem, stejně jako mateřství. 
nebo představ o mužské hrdosti, které jsou u žen někdy setrvalejší, než jsou ony mužsky hrdé postoje u mužů, a nemusí vždy souviset s postoji, které partner ženy opravdu zastává. Trend zahrnutí partnerových postojů do postojů samotných žen, co se týká rodičovství, se ukázal i v kvantitativní analýze studující postoje obecné populace k léčbě neplodnosti: charakteristiky partnerů žen (jako bylo jejich vzdělání nebo náboženství) vstupovaly do jejich postojů výrazněji než charakteristiky žen samotných, přičemž postoje samotných mužů nejsou strukturovány do té míry, v jaké jsou odpovědi žen charakteristikami mužů ovlivněny (Slepičková a Fučík 2009). Zdánlivě univerzálně platný Albertův výrok o ženách, které chtějí mít dítě svého muže, tak můžeme upravit tak, že každá žena raději zvolí dítě svého muže před dítětem někoho jiného - dárce -, byt' by to bylo její geneticky vlastní dítě. Zatímco ženské motivace $\mathrm{k}$ rodičovství jsou vnímány jako samozřejmé a trvalé, $\mathrm{v}$ př́padě otcovství ženy předjímají jeho nestálost a problematičnost.

\section{Za každou cenu?}

Úvahy o životě bez dětí jsou nevyhnutelně spojeny s definicí významu, který je rodičovství v životě jedince přikládán, předpokládaných zisků z rodičovství a ztrát, které se s nedobrovolnou bezdětností pojí. Snaha vyhnout se těmto ztrátám je především pro konverzační partnerky hlavním motorem usilování o rodičovství, byt' je dosažitelné za cenu mnoha kompromisů. Muži v mém výzkumu (a to shodně konverzační partneři samotní nebo protějšky mých konverzačních partnerek) vystupovali jako ochotnější smírit se s bezdětným životem a jako ti, kteři svým souhlasem s pokračováním v léčbě, s dárcovskými buňkami nebo s adopcí činí ústupek prrání své partnerky.

Konverzační partnerky označují sebe samy a někdy i své partnery za „rodinné“ nebo „opatrovatelské“. Zdůrazňují, že v rodičovství spatřují smysl života, a v rozhovorech se distancují od lidí, kteří se o rodičovství nezajímají nebo věnují svůj život práci či jiným aktivitám. Jedna z konverzačních partnerek přirovnává období, ve kterém se s manželem v důsledku neplodnosti ocitli, ke krizi středního věku, kdy člověk hledá smysl života a způsob, jak se cítit potřebný poté, co děti, díky jejichž permanentní príitomnosti si dřive takové otázky neměl čas prripouštět, opustily rodinu.

Své odhodlání nezůstat bezdětnou popisuje Vendula, která se připravuje na umělé oplodnění, takto:

Kdyby tohle nevyšlo, určitě bych si zaplatila ještě nějaký další dva pokusy. A když by to nevyšlo, tak jsem si říkala, že prodám byt nebo musíme prodat auto nebo já nevím, abych měla na ty pokusy. Říkám si, jednou to musí vyjít a když ne, tak bysme si adoptovali, přinejhorším. Ale nedokážu si představit, že bych byla bez dětí.

Konverzační partnerky často přemýšlí o tom, jakým způsobem by život naplnily v případě, že by léčba (ani pokus adoptovat dítě) neskončila úspěšně. Prodlužování aktivit, které uspokojivě naplňovaly dobrovolně bezdětnou fázi života nebo hledání alternativního smyslu života v koníčcích, práci, charitě, péči o prríbuzné atd., je vnímáno jako neuspokojivé, samoúčelné a neautentické a popisováno jako „,znouzectnost“ nebo marná snaha „zaplácnout díru v tom životě“. Flexibilita a různorodé možnosti bezdětného života ztrácejí s rostoucím věkem 
na atraktivitě, život je stále více definován tím, co v něm chybí. V bezdětném životě by ženy kromě možnosti vidět v dítěti „sebe sama“, tedy jakési prodloužení své existence, postrádaly také možnost předat své životní zkušenosti, sdílet svůj život s dítětem a navázat unikátní vztah, za který je vztah mezi matkou a dítětem považován.

Dítě má význam sociální, činí z člověka kompletní, plnohodnotnou bytost se smysluplnou existencí také ve vztahu k ostatním. Bezdětnost je naopak spojována s osamělostí, nezakotveností a bezcílností vlastního života. Ženy často zmiňovaly své obavy ze samoty ve stáří a z izolace mezi svými vrstevníky, kterou zažívají už nyní, jako nedobrovolně bezdětné. Mirka řekla, že dítě jí chybí jako „vstupenka do party“ vrstevníků, Jana popsala, jak se coby bezdětná cítila se svými někdejšími přáteli.

Oni ten život opravdu žili někde jinde, jezdili společně na dovolený s dětma, různě se setkávali a já jsem tam byla opravdu jako pátý kolo u vozu, byla jsem vyčleněná $\mathrm{z}$ toho kolektivu, $\mathrm{z}$ toho běžného života, který lidi žijou. Ty lidi se s náma o tom problému dokázali bavit, ale žili si dál svůj život. A já jsem ho taky tak chtěla žít. Všecky ty starosti, výlety [...]. To jsem se cítila jiná a vyčleněná, odstrčená jsem si připadala, opravdu.

Konverzační partnerky můžeme v této souvislosti rozdělit do dvou kategorií. Pro první skupinu žen platí onen imperativ „usilování za každou cenu“ (Hašková a Zamykalová 2006: odst. 20), který někdy přesahuje i pár samotný. Jsou to ženy, které bezdětný život odmítají a deklarují svou ochotu přistoupit na jakékoli řešení neplodnosti. O rodičovství některé z nich usilují samy (jako rozvedená Romana) nebo s několikátým partnerem (Vendula). Některé z nich $\mathrm{v}$ rozhovoru řekly, že jsou připraveny stávajícího partnera opustit, pokud neprristoupí $\mathrm{k}$ těm řešením neplodnosti nebo k takovému časovému horizontu rodičovství, které se jako jediné nabízejí (jako Jiřina), případně byly rozchodu z těchto důvodů blízko (v době rozhovoru těhotná Jana).

Jiné ženy svou touhu po rodičovství a představu o něm spojují s partnerským svazkem a podobě svého rodičovství a míře svého usilování o něj stanovují hranice. Rodičovství definují jako společné, prŕípadně deklarují svou touhu dát dítě svému partnerovi, který si je ,zaslouži““. Potomek je pro ně významný jako ztělesnění nebo zpečetění jejich vztahu, často tehdy, pokud se jedná o vztah s novým partnerem následující po manželství či partnerství, z nějž dítě/děti už vzešly. Společné rodičovství páru je tím, co jejich partnerství mění v rodinu, a činí tak z jejich svazku svazek trvalý. V usilování o dítě si stanovují hranice toho, co je a co není přijatelné. Jako „lámání věcí přes koleno“ obvykle označují dárcovství. Investice do léčby - časové, finanční, psychické, fyzické - jim připadají zbytečné v př́ípadě, že partnerům nemůže přinést společného potomka. Spíše než k volbě této cesty asistované reprodukce jsou ochotnější k adopci - je přijatelnější především proto, že zachovává „společné“ rodičovství páru, altruistické motivace $\mathrm{k}$ adopci se v rozhovorech objevily jen několikrát. Pro jiné ženy z této skupiny je ve chvíli, kdy geneticky vlastního potomka a společného potomka nemůžou mít, snazši smiřit se s bezdětným životem (nebo setrváním u stávající, tř́ičlenné rodiny). Zdůrazňovaly, že nejsou ochotny touze po dítěti obětovat svůj partnerský vztah nebo dobrou atmosféru v rodině, která se ukazuje být léčbou nebo neshodami kolem ní narušována. 
Hranice toho, co je pár ochoten podstoupit, je často dána také finančními možnostmi, pokud je zřejmé, že více než tři pojišt'ovnou hrazené pokusy si partneři nemohou dovolit. Zadlužit se kvůli léčbě je pro většinu konverzačních partnerek nepřijatelné, protože ani to nepřinese jistotu, že bude úspěšná. Některé konverzační partnerky definují hranici přijatelnosti léčby svými vlastními fyzickými a psychickými možnostmi - uvádějí, že jejich potenciál zvládnout nežádoucí účinky hormonální stimulace a psychicky se vyrovnat $\mathrm{s}$ dalším neúspěchem je limitovaný. Limitují jej také legislativní hranice asistované reprodukce, možnost uchýlit se k nelegálním aktivitám nebo praktikám na hranici zákona s cílem dosáhnout úspěšné léčby nebo adopce většina žen také odmítá.

Na hranice přijatelnosti má vliv také osobní zkušenost s neúspěšnou léčbou - ta se může ukázat být př́liš vyčerpávající a plánovaný počet pokusů je v jejím průběhu spíše snižován. Naopak ale může přiblížit těhotenství natolik, že její ukončení je velmi obtížné - po vyrovnání se s neúspěchem se dostavuje nová vlna odhodlání a nadějí (Slepičková 2011).

Deklarace odhodlání k rodičovství a usilování o něj není překvapivá vzhledem k charakteristikám konverzačních partnerů jako „neplodných“. Lidé, kteří o rodičovství neusilují, kvưli neplodnosti jen těžko navštíví lékaře, nemusí se o ní ani dozvědět. Zároveň je usilování o rodičovství a jeho prezentace jako nezpochybnitelně pozitivního životního cíle součástí mateřské (rodičovské) normy a způsobem, jak se vyhnout nálepce dobrovolné bezdětnosti, která $\mathrm{v}$ některých př́ípadech představuje zásadnější stigma než bezdětnost nedobrovolná (Slepičková 2005). Snaha o rodičovství a využití jakýchkoli prostředků k jeho dosažení je, na rozdíl od smíření se s bezdětností, pozitivně sankcionovaným chováním, ale usilování o rodičovství nemá podobu odhodlání udělat cokoli.

Odkazy k niternosti a „přirozenosti“ rodičovství zakrývají jeho sociální význam, který je však v rozhovorech dobře zřetelný. Kromě bezpodmínečné a trvalé lásky, která je vzhledem k pomíjivosti a dočasnosti postmoderních intimních vztahů zvlášt' podstatnou motivací k rodičovství (Beck 2004), je rodičovství zdrojem dospělého a normálního statusu. Je integrujícím činitelem a ochranou proti samotě a také před vědomím omezenosti a konečnosti vlastní existence, zařazuje nás mezi vrstevníky a chrání před izolací. I přes demografy a sociology popisované kulturní a hodnotové proměny postmoderní společnosti týkající se rodiny, kterým dominuje téma narůstající bezdětnosti a vymírání populací, jsou výpovědi neplodných často výpověd’mi o životě ,,v plodné vesnici“, v níž všichni mají děti - kromě nich samotných.

\section{Závěr}

Rozhodování neplodných párů o rodičovství ukazuje, že různé typy rodičovství nejsou stejně žádoucí - některé $\mathrm{z}$ nich jsou vnímány jako větší kompromis ve vztahu k původním představám o rodičovství než jiné, některé jsou přijatelnější, jiné méně či vůbec. Legitimita rodičovství jako unikátního a nenahraditelného vztahu - se samotným dítětem, s partnerem, s okolím - je tím větší, čím je toto pouto viditelnější a rozeznatelnější, čím víc můžeme $\mathrm{v}$ dítěti vidět sami sebe, své geny a prodloužení své existence, čím více v něm můžeme vidět geny svého partnera a čím více je tento vztah zřejmý i pro ostatní.

Unikátní vztah mezi rodiči a dětmi je vnímán jako vztah, který zprostředkovávají geny. Právě geny určují, kdo je s kým spřízněn, jsou to biologické elementy, jejichž význam je 
především symbolický (Schneider 1972). To, zda jsou geny „dobré“ či ,špatné“, je pro zdar rodičovství klíčové. Důraz na geny v konceptu př́ibuzenství dnes doplňuje nebo nahrazuje primárnost pokrevní vazby, společné krve: Lebner (2000) píše o genetizaci příbuzenství, která souvisí s medikalizací společnosti a s intenzivním a mediálně zajímavým výzkumem $\mathrm{v}$ této oblasti. Geny získávají pro rodičovství na důležitosti díky tomu, že o nich víme a slýcháme stále častěji. Autorita genů je navázána na autoritu biomedicíny coby vědecké instituce produkující nezpochybnitelná fakta o člověku. Medicína „posvěcuje“ všechny cesty k rodičovství, které se odehrávají v jejím poli, zbavuje je rizik, nečistot či pochybností na úrovni fyzické (při manipulaci s materiálem, který by byl ve všech jiných kontextech vnímán jako nečistý) i morální. Obrat k jejím vyspělým technologiím při snaze o početí je legitimizován jako „volání přírody“, jako vyslyšení přirozené touhy člověka po šíření vlastních genů a jako následek zoufalství ze situace, kdy je naplnění této touhy problematické. Medicína dělí tělo na buňky a proces početí na jednotlivé úkony, poruchy označuje jako „nemoci“ a jejich řešení jako „léčbu“. Známá a vyčíslitelná rizika nám dávají pocit jejich zvládnutelnosti a ochrany proti nim. Využít služeb medicíny pro pomoc s početím je pozitivně sankcionované chování, zatímco adopce je extrémní a vysoce rizikovou variantou rodičovství. („Cože? Už? Nechcete se ještě chvíli zkusit léčit?“ - tak parafrázuje reakce svých prŕíbuzných na plán adoptovat dítě Mirka.) Asistovaná reprodukce je součástí soukromé sféry páru, je to problém zamknutý do sféry léčení a nemoci, zatímco adopce je subjektem sféry veřejné, v níž je viditelná a regulovaná. Pro léčbu je důležitý věk partnerů, povaha jejich vztahu a fyzická kondice konkrétních částí jejich těl, do adopčního řízení vstupuje řada dalších otázek a faktorů, které mají ukázat způsobilost partnerů k rodičovství.

Důraz na rozeznatelnost pak zvýhodňuje takové typy rodičovství, které přinášejí fyzickou podobnost potomka a rodičů, nebo alespoň těhotenství jako nezpochybnitelný důkaz rodičovského pouta a nabízí způsob vyvinutí si „přirozeného“ vztahu k dítěti. Těhotenství z žen a viditelná genetická spř́zněnost potomka z mužů odnímá stigma neplodnosti, což je jedním z důvodů, proč je pro ženy více než pro muže přijatelné rodičovství postrádající biologickou vazbu.

Výzkumné rozhovory ukázaly, jak obtížné je vyjednávání o rodičovství v rámci partnerského páru. Zatímco muži předjímají ženskou fixaci na mateřství jako takové a někdy ustupují svým partnerkám, které touží po jakémkoli rodičovství, ženy předjímají mužskou „hrdost“ a jsou ochotny vzdát se genetické spř́zněnosti se svými dětmi ve prospěch partnerů. Odkaz k těhotenství a porodu (tedy biologickým procesům) jako k ženskému podílu na rodičovství (které přitom postrádá komponentu, která je muži a ženami vnímaná jako klíčová) působí jako naturalizace tohoto modelu rozhodování, který je však velmi genderově stereotypní - od ženy se očekává, že partnerovi „dá“ jeho dítě, že jeho otcovství stvrdí genetickou vazbou $\mathrm{k}$ dítěti, zatímco její vztah $\mathrm{k}$ dítěti je zprostředkován hormonálně.

Rodičovství vztah ztělesňuje, čímž jej činí nezpochybnitelným a trvalým. Zároveň ale do vyjednávání v rámci partnerských párů vstupují odlišné významy rodičovství i bezdětnosti pro muže a ženy, odlišná míra stigmatu neplodnosti, jejich různá pozice v léčbě neplodnosti a také rozdílná zkušenost $\mathrm{s}$ touto léčbou. Zejména $\mathrm{v}$ oblasti reprodukce využívající dárců nebo adopce mají muži a ženy odlišné postavení a během svého vyjednávání o mateřství a otcovství čelí jinému typu překážek (Lupton a Barclay 1997) - ukazuje to na způsob, jakým 
reprodukční technologie konzervují a zdůrazňují genderové rozdíly v rodičovství (Ettore 2002).

Zvažování adopce je v rozhodování neplodných párů odsunováno do pozadí. Potěšení z pocitu, že člověk vidí v dítěti sám sebe, že jeho prostřednictvím získá pokračovatele pro své geny, je důležitou motivací k rodičovství, která nahradila důraz na ekonomický př́nos potomků. Tohoto potěšení je možné dosáhnout jen skrze takový typ rodičovství, do nějž alespoň částečně vstupuje genetická výbava rodičů. $Z$ výzkumných rozhovorů se zdá, že investice do dítěte, které nám - prostřednictvím zděděných genů - nemůže zajistit „expanzi za hranice vlastního života“ (Hoffman a Hoffman 1973 in Rabušic 2001: 287), se může ukázat jako prŕlišs vysoká.

Právě křehkost současných partnerských svazků může být tím, co má vliv na upevnění důležitosti biologického rodičovství. Veřejný strach z eroze tradičního rodinného života a víru v nezpochybnitelné pokrevní či genetické pouto mohou zvyšovat i populární příběhy adoptovaných dětí hledajících své biologické rodiče. Tyto příběhy, stejně jako snaha všech typů rodičovství imitovat rozeznatelnost (a tedy i nezpochybnitelnost) rodičovství biologického, ukazují, že různé typy rodičovství jsou akceptovány v odlišné míře.

Výpovědi neplodných párů zpochybňují představu o normě „usilování za každou cenu“ (Hašková a Zamykalová 2006). Jejich rozhodování má svoje hranice a limity. Viděli jsme, že i adopce se za určitých okolností může stát bezpečnější a přijatelnější cestou k rodičovství než nekonečná léčba, v níž nás jeden nezdar vrací do startovního bodu. Adopce je cestou z osamělosti zažívané při léčbě a je, na rozdíl od nejistých výsledků asistované reprodukce, reálnou tranzicí k rodičovství. Poukázali jsme na to, že významnou roli ve vzorcích rozhodování hraje především čas, který uběhl od počátku léčby, množství vyzkoušených procedur a také věk (především žen). Podstatný je také význam rodičovství pro jednotlivé páry - můžeme je rozdělit na ty, pro které je rodičovství především statusem či vztahem s okolím a kteří jej nadřazují svému partnerskému vztahu, a na ty, kteří vidí rodičovství především jako ztělesnění vztahu a ani v př́padě, že by jejich snahy o početí neměly úspěch, nezvažují ukončení partnerského vztahu či navázání nového.

Způsoby, jakými konverzační partneři a partnerky konstruovaly budoucí pouto ke svým potomkům, neukazují na zneplatňování dominantní ideologie rodičovství jako založeného na genetických poutech, ale naopak na potřebu řešit určitý kognitivní rozpor zdůrazňováním těch aspektů rodičovství, které odpovídají tradiční rodinné ideologii, a zakrývání těch, které ji narušují. S cílem projít legitimními a nedotknutelnými kategoriemi rodičovství (Thompson 2005) budoucí rodiče manipulují s různými kategoriemi rodičovství tak, aby zdůraznili svůj podíl, at' už jej dosáhli prostřednictvím těhotenství s geneticky nespř́zněným potomkem, nebo výchovou a láskou, kterou mu poskytují. Vytvářejí si svůj vlastní př́iběh početí, v němž zdůrazňují primárnost svého vztahu k dítěti, bez ohledu na to, jakou má podobu, a marginalizují jiné vztahy. ${ }^{10}$

10 Ragoné (1997) ve výzkumu náhradního mateřství ukazuje, jak všichni aktéři zdůrazňují ty aspekty procesu, které jsou v souladu s tradičními představami o rodičovství, a redefinují ty ostatní: Náhradní matky tak zdůrazňují své altruistické motivace a náhradní mateřství prezentují jako rozšírení přirozené ženské role spojované s mateřstvím a s obětavou pomocí druhým. Marginalizují 
Akceptace rodičovství dosaženého díky dárcovství či adopci neznamená vnášení nových prvků a vazeb do stávající konstrukce rodičovství, ale snahu integrovat do ní všechny ,abnormality“ prostřednictvím důrazu na „přírodni““ nebo naopak „kulturni'“ komponentu rodičovství. Zároveň ukazuje, že dichotomii př́roda/kultura jde za určitých okolností skrze zdůraznění sociálních vazeb přepracovat, a dosáhnout tak setření hranic mezi genetickým vztahem a citovým poutem.

\section{Literatura}

AKKER, VAN DEN, Olga. The Acceptable Face of Parenthood: The Relative Status of Biological and Cultural Interpretations of Offspring in Infertility Treatment. Psychology, Evolution \& Gender, 2001, roč. 3, č. 2, s. 137-153. ISSN 1461-6661.

BAILEY, Lucy. Refracted Selves? A Study of Changes in Self-Identity in the Transition to Motherhood. Sociology, 1999, roč. 33, č. 2, s. 335-352. ISSN 0038-0385.

BECK, Ulrich. Riziková společnost na cestě k jiné moderně. Praha: Sociologické nakladatelství, 2004. 431 s. ISBN 9788086429328.

BERNARDES, Jon. Multidimensional Developmental Pathways: A Proposal to Facilitate the Conceptualisation of 'Family Diversity'. The Sociological Review, 1986, roč. 34, č. 3, s. 590-610. ISSN 0038-0261.

CONRAD Peter. The Medicalization of Society: On the Transformation of Human Conditions into Treatable Disorders. Baltimore: Johns Hopkins University Press, 2007. 241 s. ISBN 9780801885846.

ETTORE, Elizabeth. Reproductive Genetics, Gender and the Body: 'Please Doctor, may I have a Normal Baby?'. Sociology, 2000, roč. 34, č. 3, s. 403-420. ISSN 0038-0385.

GLASER, Barney G.; STRAUSS, Anselm L. The Discovery of Grounded Theory. Chicago: Aldine. 271 s. ISBN 0202302601.

HAŠKOVÁ, Hana; ZAMYKALOVÁ, Lenka. Mít děti - co je to za normu? Čí je to norma? Biograf, 2006, č. 40-41, s. 3-53. ISSN 12115770.

HOFFMAN, Lois Wladis; HOFFMAN, Martin L. The Value of Children to Parents. In FAWCET, J. T. (ed.) Psychological Perspectives on Population. New York: Basic Books, 1973, s. 19-76. ISBN 0465066739.

ILLICH, Ivan. Limits to Medicine: Medical Nemesis, the Expropriation of Health. London: Marion Boyars Publishers Ltd, 2000. 294 s. ISBN 0714529931.

KONOPÁSEK, Zdeněk. Co si počít s počítačem v kvalitativním výzkumu: Program Atlas/ti v akci [online]. Biograf. 1997, č. 12 [cit. 2011-04-26]. Dostupné na www: <http://biograf.org/clanky/ clanek.php?clanek=1205>. ISSN 12115770.

LEBNER, Ashley. 'Genetic Mysteries' and International Adoption: The Cultural Impact of Biomedical Technologies on the Adoptive Family Experience. Family Relations, 2000, roč. 49, č. 4, s. 371-377. ISSN 01976664.

svou biologickou spřízněnost s dítětem a zdůrazňují pečovatelské a vztahové aspekty mateřství. Naopak touha budoucích rodičů po geneticky vlastním potomkovi legitimizovala všechny kroky, které $\mathrm{k}$ tomuto cíli směřují. Budoucí matky zdůrazňovaly, že dítě bylo stvořeno $\mathrm{v}$ jejich srdci a myšlenkách ještě dřive, než se na scéně objevila náhradní matka, která je popisována jako nahrazující jen konkrétní část těla budoucí matky. 
LETHERBY, Gayle. Challenging Dominant Discourses: Identity and Change and the Experience of 'Infertility' and 'Involuntary Childlessness'. Journal of Gender Studies, 2002, roč. 11, č. 3, s. 277-288. ISSN 0958-9236.

LIPPMAN, Abby. The Politics of Health: Geneticization versus Health Promotion. In SHERWIN, S. (ed.). The Politics of Women's Health: Exploring Agency and Autonomy. 1998. Philadelphia: Temple University Press, s. 64-82. ISBN 1566396336.

LORBER, Judith. Choice, Gift or Patriarchal Bargain: Women's Consent to In Vitro Fertilization in Male Infertility. Hypatia, 1989, roč. 4, č. 3, s. 23-36. ISSN 0887-5367.

LUPTON, Deborah; BARCLAY, Lesley. Constructing Fatherhood: Discourses and Experiences. London: SAGE, 1997. 192 s. ISBN 9780761953401.

MASON, Mary-Claire. Male Infertility--Men Talking. New York: Routledge, 1993. 224 s. ISBN 9780415072892.

MIALL, Charlene, Emily. Authenticity and the disclosure of the information preserve: The case of adoptive parenthood. Qualitative Sociology, 1989, roč. 12, č. 3, s. 279-302. ISSN 1573-7837.

MIALL, Charlene, Emily. Community Constructs of Involuntary Childlessness: Sympathy, Stigma, and Social Support. Canadian Review of Sociology/Revue canadienne de sociologie, 2008, roč. 31, č. 4, s. 392-421. ISSN 1755618X.

RABUŠIC, Ladislav. Kde ty všechny děti jsou?: porodnost v sociologické perspektivě. Praha: Sociologické nakladatelství, 2001. 265 s. ISBN 9788086429014.

RAGONÉ, Helena. Chasing the Blood Tie. In LAMPHERE, L., RAGONÉ, H., ZAVELLA, P. Situated Lives: Gender and Culture in Everyday Life. New York: Routledge, 1997, s. 110-127. ISBN 9780415918060.

SEVÓN, Eija. Timing Motherhood: Experiencing and Narrating the Choice to Become a Mother. Feminism \& Psychology, 2005, roč. 15, č. 4, s. 461-482. ISSN 0959-3535.

SCHNEIDER, David. What is Kinship All About? In REINING, P. (ed.). Kinship Studies in the Morgan Centennial Zdar. Washington, DC: Anthropological Society of Washington, 1972, s. 32-63. ISBN 9780874747966.

SLEPIČKOVÁ, Lenka. Nedobrovolná bezdětnost jako medializovaný problém. Disertační práce. Masarykova univerzita, Brno, 2011.

SLEPIČKOVÁ, Lenka. Vajičko, spermie, zkumavka... A gender. Postoje českých žen a mužů k asistované reprodukci a adoptivnímu rodičovství. Gender - rovné př́ležitosti-výzkum, 2007, roč. 8, č. 2 , s. 68-75. ISSN 1213-0028.

SLEPIČKOVÁ, Lenka; FUČÍK, Petr. Sociální kontext postojů k řešení neplodnosti. Sociologický časopis, 2009, roč. 45, č. 2, s. 9-29. ISSN 00380288.

THOMPSON, Charis. Making Parents: The Ontological Choreography of Reproductive Technologies. Cambridge MA: MIT Press, 2005. 380 s. ISBN 0262201569.

VIDOVIĆOVÁ, Lucie; GREGOROVÁ, Eva. Věkové normy v sociologické perspektivě. Sociálni studia, 2007, roč. 4, č. 1-2, s. 201-216. ISSN 1214-813X.

WEBB, Russell. E.; DANILUK, Judith. C. The End of the Line: Infertile Men's Experiences of Being Unable to Produce a Child. Men and Masculinities, 1999, roč. 2, č. 1, s. 6-25. ISSN 1097-184X.

WEGAR, Katarina. Adoption, Family Ideology, and Social Stigma: Bias in Community Attitudes, Adoption Research, and Practice. Family Relations, 2000, roč. 49, č. 4, s. 363-370. ISSN 01976664. 


\section{Autorka}

Lenka Slepičková pracuje jako výzkumná pracovnice na Fakultě sociálních studií Masarykovy univerzity. Zabývá se sociologií rodiny a sociologií medicíny. Její aktuální výzkumné projekty se týkají medikalizace neplodnosti prostřednictvím reprodukčních technologií a perspektivy dětských aktérů týkající se rodiny a blízkých vztahů.

Kontakt: lenka.slepickova@gmail.com 